\title{
The suitability and attraction of the population of the United Arab Emirates for the study of genetic inheritance in scoliosis
}

\author{
K Bagnall, A Al Kaabi, H Al Hamsi, T Al Mazrouee, A D'souza \\ From 8th International Conference on Conservative Management of Spinal Deformities and SOSORT 2011 \\ Annual Meeting \\ Barcelona, Spain. 19-21 May 2011
}

\section{Background}

Recently, significant advances have been made in understanding the aetiology of adolescent idiopathic scoliosis (AIS) in the area of genetic inheritance. Essential to the success of these studies is the finding of large families with several cases of AIS from which blood samples can be collected and analysed. The emirati culture is unique and encourages large families with many children, often several wives with the same husband, and many cases of consanguinity especially among first cousins. This complex family structure might very well be suited to provide more appropriate examples for the study of genetic heritage in AIS than the more typical western family.

\section{Material and methods}

The genealogical history of 15 extended emirati families was collected for 4 generations which would approximate that required for the study of AIS. The number of children in each family and the incidence of consanguinity among first cousins were calculated. These data were compared with similar, published data for western families.

\section{Results}

The average number of children per family among the emirati population was 6.29 (often $>10$ ), approximately $3 \mathrm{x}$ that of the average western family. In each family there were several examples of multiple wives and first cousin marriages. Two families were found in which at least one person had AIS.

UAE University, Al Ain, United Arab Emirates

\section{Conclusions}

These results suggest that the unique, well controlled structure of the emirati families lend themselves to being excellent for extensive study of the genetic inheritance aspects of the aetiology of AIS because of the greater familial component.

Published: 27 January 2012

doi:10.1186/1748-7161-7-S1-072

Cite this article as: Bagnall et al:: The suitability and attraction of the population of the United Arab Emirates for the study of genetic inheritance in scoliosis. Scoliosis 2012 7(Suppl 1):O72.

Submit your next manuscript to BioMed Central and take full advantage of:

- Convenient online submission

- Thorough peer review

- No space constraints or color figure charges

- Immediate publication on acceptance

- Inclusion in PubMed, CAS, Scopus and Google Scholar

- Research which is freely available for redistribution

(0) 2012 Bagnall et al; licensee BioMed Central Ltd. This is an open access article distributed under the terms of the Creative Commons 